\title{
EFFECT OF IRRIGATION REGIMES, NITROGEN, AND MULCHING TREATMENTS ON WATER PRODUCTIVITY OF TOMATO UNDER DRIP IRRIGATION SYSTEM
}

\author{
Attia*, M. M., A. Swelam**, A. A. Sallam* and A. M. Osman*
}

\section{ABSTRACT}

A field experiment was conducted at El-Intelaq area, West Nubaria region, Behaira Governorate $\left(31^{\circ} 02^{\prime} \mathrm{N}, 30^{\circ} 28^{\prime} \mathrm{E}\right.$, and $6.7 \mathrm{~m}$ above mean sea level), Egypt during the 2012 and 2013 summer growing seasons to study the effect of three irrigation treatments (i.e., $I_{1}=75 \%, I_{2}=100 \%$, and $I_{3}=$ $125 \%$ of reference ETo, which was estimated from class ' $A$ ' pan evaporation and Kpan=0.75, two nitrogen fertilizer levels (i.e., $N_{l}=75 \%$, and $N_{2}=100 \%$ of recommended nitrogen rate), and two crop residuals mulching treatments (i.e., $M_{0}=$ without mulch, and $M=$ with mulch) on tomato yield, amounts of applied irrigation water, water consumption, applied water productivity (AWP), leaf water potential, and to develop a local tomato crop coefficient $(K c)$ and yield response factor $(K y)$ under the experimental conditions. Results indicated that, the tested variables had significant effect on tomato yield in the two growing seasons. The highest tomato fruit yields of 80.57 and 64.42 ton/ha were obtained as a result of the interaction of $I_{3}(125 \%$ ETo $)$ and $N_{2}$ treatment in the two growing seasons, respectively. Total depths of applied irrigation water and water consumption of 816.2 and $838.0 \mathrm{~mm}$ and 573 and $574 \mathrm{~mm}$ were recorded in the $1^{\text {st }}$ and $2^{\text {nd }}$ growing seasons, respectively, for the $I_{3}$ irrigation treatment. In both seasons, the highest AWPs values were 9.73 and $9.42 \mathrm{~kg} / \mathrm{m}^{3}$ due to the combined effect of irrigation treatment $I_{1}\left(75 \% E_{\text {pan }}\right)$ and $N_{2}(100 \%$ of recommended nitrogen fertilizer). Leaf water potential values were lower with the high applied water treatment than with the stressed irrigation treatment. Average crop coefficient values were 0.51 at initial growth stage during June and reached its maximum value of 0.98 during August, and then decreased to 0.71 during October. The local seasonal average tomato crop coefficient $\left(K_{C}=E T c / E T o\right)$ and yield response factor $(K y)$ values under the experimental conditions were 0.74 and 0.82 , respectively.

\footnotetext{
*Soils, Water and Environment Research Institute (SWERI); Agricultural Research Center (ARC); Egypt.

**Agricultural Engineering Department, Faculty of Agriculture, University of Zagazig, Currently: International Centre for Agricultural Research in the Dry Areas (ICARDA)
} 
It was concluded that, under similar field conditions, applying a depth of water equal to $125 \%$ of $\mathrm{ET}_{\mathrm{o}}$ and $100 \%$ of the recommended nitrogen fertilizer, and adding plant residue mulch is recommended for maximum tomato yield in the studied sandy soils under drip irrigation systems.

Key words: tomato yield, applied irrigation water, water consumption, applied water productivity, crop coefficient, yield response factor, drip irrigation.

\section{INTRODUCTION}

$\mathrm{W}$ ater scarcity has become an increasing constraint to the economic development of countries in arid and semi-arid regions, e.g. Egypt, particularly for food production, which represents the biggest water user. To cope with that, many countries have been exploiting their non-renewable fossil water to relieve the immediate pressure of water stress, thus depleting their resource base and undermining their long-term economic development and food security. With the increase of water stress and the limited potential for additional water supply in recent years, improving water productivity is increasingly important. In the agricultural sector, this effort has been expressed as "more crop and higher value per drop" (FAO, 2000). Currently and in the future, irrigation management will shift from emphasizing production per unit land area towards maximizing the production per unit of water consumed, i.e. the water productivity.

Drip irrigation has been used extensively for vegetable crops to save water, fertilizer, and improve production and crop quality. Similarly, mulching has been used for moisture conservation and enhancing the quality of crop products. Drip irrigation in combination with mulch is one of the best management methods that can significantly improve the irrigation practice. Surface mulches have been used to improve soil water retention, reduce soil temperature, and reduce wind velocity at the soil surface of arid lands (Kay, 1978; Jalota and Prihar, 1998). Drip irrigation has proved its superiority over other conventional methods of irrigation, especially in the cultivation of fruits and vegetables, due to precise and direct application of water in the root zone. A considerable water saving, increased growth 
development and yield of vegetables under drip irrigation has been reported by (Bhella, 1988; Raina et al., 1999; Imtiyaz et al., 2000).

Applied irrigation water amounts can affect the number of fruits per plant, average weight of marketable fruits and total fruit yield/ha. In addition, significant improvement in number of fruits and total fruit yield/ha were reported as a result of mulch treatments. Application of $440 \mathrm{~mm}$ water in two-day irrigation interval using drip system with straw mulch demonstrated economic profitable and improved water productivity due to consumption of less water (Berihun, 2011). In a study that compared the use of two different types of mulch (polyethylene and straw), mulching significantly increased fruit yield, fruit diameter, and firmness of tomato when compared to an un-mulched control. The highest yield for each mulch (81.12 $\mathrm{t} / \mathrm{ha}$ for polyethylene, and $79.49 \mathrm{t} / \mathrm{ha}$ for straw) was obtained when $50 \%$ of water requirement was applied. The highest water productivity of $192 \mathrm{~kg} / \mathrm{ha} / \mathrm{mm}$ was obtained with $50 \%$ of full water application under polyethylene mulch. The study revealed that drip irrigation with mulch has an explicit role in increasing the land and water productivity of tomato (Biswas et al., 2015). Nitrogen fertilizer application has also been reported to positively impact yield. The application of $90 \mathrm{~kg} \mathrm{~N} \mathrm{ha}^{-1}$ produced higher fruit yield than the control treatment by $115 \%, 78 \%$, and $82 \%$ in 2004/2005, 2005/2006, and 2006/2007 seasons, respectively (Samalia et al., 2011).

The main objectives of this study were to test the effect of three irrigation treatments, two mulch treatments, and two nitrogen fertilizer levels on tomato production, amount of applied irrigation water, water consumptive use, applied water productivity (AWP), and leaf water potential, and to develop a local tomato crop coefficient $(\mathrm{Kc})$ and yield response factor $(\mathrm{Ky})$ under drip irrigation system in sandy soils.

\section{MATERIALS AND METHODS}

Experimental site description:

A field experiment was carried out during the 2012 and 2013 summer seasons at the experimental farm of El-Intelak area, West Nubaria Region $\left(31^{\circ} 02^{\prime} \mathrm{N}, 30^{\circ} 28^{\prime} \mathrm{E}\right.$, and $6.7 \mathrm{~m}$ above mean sea level), El-Behiera Governorate, Egypt. The experimental site represents the newly reclaimed sandy soils of Nubaria region. Soil samples were collected from two depths 
(0-30 and 30-60cm) to determine main soil physical and chemical properties at the experimental site. The soil physical parameters (particle size distributions and soil texture class) were determined according to FAO (1970). Soil-moisture constants (soil field capacity, F.C.; wilting point. W.P.; and available soil moisture, ASM) were determined on mass basis by a pressure extractor apparatus, and soil bulk density values were determined in undisturbed soil samples using the core method (Black and Hartge, 1986). The soil chemical parameters (electrical conductivity (EC), soil reaction $(\mathrm{pH})$, cations, and anions concentrations) were determined according to Page et al. (1982). The main physical and chemical properties of the soil at the experimental site are listed in Tables 1 and 2.

Table 1. Soil hydro-physical properties of the study area.

\begin{tabular}{|l|c|c|c|c|c|c|c|c|}
\hline $\begin{array}{l}\text { Soil depth } \\
(\mathrm{cm})\end{array}$ & $\begin{array}{c}\text { FC } \\
(\%)\end{array}$ & $\begin{array}{c}\text { WP } \\
(\%)\end{array}$ & $\begin{array}{c}\text { ASM } \\
(\%)\end{array}$ & $\begin{array}{c}\mathrm{BD}(\mathrm{g} \\
\left.\mathrm{cm}^{-3}\right)\end{array}$ & \multicolumn{2}{|c|}{$\begin{array}{c}\text { Particle size } \\
\text { distribution }\end{array}$} & $\begin{array}{c}\text { Texture } \\
\text { Class }\end{array}$ \\
\hline & & & & & $\begin{array}{c}\text { Sand } \\
\%\end{array}$ & $\begin{array}{c}\text { Silt } \\
\%\end{array}$ & $\begin{array}{c}\text { Clay } \\
\%\end{array}$ & \\
\hline $0-30$ & 11.05 & 5.2 & 5.85 & 1.56 & 90.9 & 3.6 & 5.5 & $\begin{array}{l}\text { Sand } \\
30-60\end{array}$ \\
\hline Average & 10.35 & 4.4 & 4.95 & 1.77 & 91.5 & 2.8 & 5.7 & Sand \\
\hline
\end{tabular}

Table 2. Soil chemical properties.

\begin{tabular}{|l|c|c|c|c|c|c|c|c|c|}
\hline \multirow{2}{*}{$\begin{array}{l}\text { Soil depth } \\
(\mathrm{cm})\end{array}$} & \multirow{2}{*}{$\begin{array}{c}\mathrm{EC} \\
(\mathrm{dS} / \mathrm{m})\end{array}$} & $\mathrm{pH}$ & $\begin{array}{c}\mathrm{Ca}^{2} \\
+\end{array}$ & $\begin{array}{c}\mathrm{Mg} \\
2+\end{array}$ & $\begin{array}{c}\mathrm{Na} \\
+\end{array}$ & $\mathrm{K}^{+}$ & $\begin{array}{c}\mathrm{HC} \\
\mathrm{O}_{3}^{-}\end{array}$ & $\begin{array}{c}\mathrm{C} \\
1^{-}\end{array}$ & $\begin{array}{c}\mathrm{SO} \\
4^{2-}\end{array}$ \\
\hline \multirow{2}{*}{$0-30$} & 1.38 & 9. & 1.2 & 0.6 & 1. & 0. & & 1.18 & 0.7 \\
& 2 & 5 & 0 & 60 & 20 & 1.18 & 8 & 5 \\
\hline \multirow{2}{*}{$30-60$} & 1.32 & 9. & 1.1 & 0.5 & 1. & 0. & & 1. & 0.6 \\
& & 3 & 0 & 5 & 44 & 15 & 1.02 & 6 & 3 \\
\hline
\end{tabular}

Samples from irrigation water at the experimental site were collected and the analysis is presented in Table 3.

Table 3. Analysis of irrigation water at the experimental site.

\begin{tabular}{|c|c|c|c|c|c|c|c|c|}
\hline \multicolumn{7}{|c|}{ Soluble anions and cations (meq/L) } & \multirow{2}{*}{$\begin{array}{c}\text { EC } \\
(\mathrm{dS} / \mathrm{m})\end{array}$} & \multirow{2}{*}{$\mathrm{pH}$} \\
\hline $\mathrm{HCO}_{3}{ }^{-}$ & $\mathrm{SO}_{4}{ }^{2-}$ & $\mathrm{Cl}^{-}$ & $\mathrm{Na}^{+}$ & $\mathrm{K}^{+}$ & $\mathrm{Ca}^{2+}$ & $\mathrm{Mg}^{2+}$ & & \\
\hline 1.6 & 0.82 & 1.8 & 2.1 & 0.17 & 1.6 & 0.4 & 0.42 & 9.37 \\
\hline
\end{tabular}

Experimental design and tested variables:

A split-split plot design with four replicates was used to conduct the field experiment. The main plots were assigned to the irrigation treatments, 
while the sub-plots were assigned to the nitrogen levels, and the sub-subplots were assigned to the mulch treatments. The experimental unit consists of four drip lines.

The tested variables in this experiment were as follows:

Irrigation treatments (main plots):

$\mathrm{I}_{1}=$ irrigation with amounts of water equal to $75 \%$ of $\mathrm{ET}_{\mathrm{o}}$

$\mathrm{I}_{2}=$ irrigation with amounts of water equal to $100 \%$ of $\mathrm{ET}_{\mathrm{o}}$

$\mathrm{I}_{3}=$ irrigation with amounts of water equal to $125 \%$ of $\mathrm{ET}_{\mathrm{o}}$

Nitrogen levels (sub-plots):

$\mathrm{N}_{1}=75 \%$ of the recommended nitrogen rate

$\mathrm{N}_{2}=100 \%$ of the recommended nitrogen rate

Mulch treatments (sub-sub-plots):

$\mathrm{M}=$ mulching with plant residues (groundnuts straw)

$\mathrm{M}_{0}=$ without mulch.

Agronomic practices:

Seedlings of tomato crop (var. Castle Rock) were transplanted on June 8, 2012 and on June 11, 2013 of the first and second growing seasons, respectively. During land preparation, $24 \mathrm{~m}^{3} / \mathrm{ha}$ of chicken manure were added. During the growing seasons, nitrogen fertilizer (as ammonium nitrate, $33 \% \mathrm{~N}$ ) was added with irrigation water through fertilizer tanks with injection at the rates of $166 \mathrm{~kg} \mathrm{~N} / \mathrm{ha}(100 \%), 286 \mathrm{~kg} \mathrm{~K}_{2} \mathrm{O} / \mathrm{ha}$ (as potassium sulfate, $50 \% \mathrm{k}_{2} \mathrm{O}$ ), and $71 \mathrm{~kg} \mathrm{P}_{2} \mathrm{O}_{5} /$ ha as phosphoric acid (80\%) were injected through the irrigation water after transplanting tomato seedlings. Tomato fruits were collected several times up to the $10^{\text {th }}$ of October 2012, and the $5^{\text {th }}$ of October 2013 in the first and second seasons, respectively. All cultural practices for tomato production at this area were followed.

A surface drip irrigation system was used to conduct the experiments. The drip system includes an irrigation pump (50 hr with discharge of $150 \mathrm{~m}^{3} / \mathrm{hr}$ ) connected to sand and screen filters and a fertilizer injector tank. Main line is made of PVC pipe of $63 \mathrm{~mm}$ diameter, while drip lateral lines of $16 \mathrm{~mm}$ diameter are connected to the main line. Each lateral is $25 \mathrm{~m}$ long and 0.8 $\mathrm{m}$ apart. Standard built-in emitters of $4.0 \mathrm{l} / \mathrm{h}$ discharge at operating pressure of 1.0 bar were spaced $0.5 \mathrm{~m}$ apart on the lateral line. Drip irrigation efficiency parameters including Christiansen coefficient and emission 
uniformity were determined. The values of these parameters were 0.94 and 0.92 , respectively. The measured actual emitter average discharge rate was $3.8 \mathrm{l} / \mathrm{h}$.

\section{Studied characters:}

\section{Irrigation applied water $(A W)$ :}

The AW was calculated according to the equation given by Vermeiren and Jopling (1984) for drip system as follows:

where:

$$
A W=\frac{E T o \times K c \times I}{D u}+L R
$$

AW = Depth of applied irrigation water $(\mathrm{mm})$.

$\mathrm{ET}_{\mathrm{p}}=$ Potential evapotranspiration $\left(\mathrm{mm} \mathrm{d}^{-1}\right)$.

$\mathrm{Kr}=$ Reduction factor, that depends on ground cover, a value of 1.0 was used (where the spacing between drip lines is less than $1.8 \mathrm{~m}$, James, 1988).

I = Irrigation intervals (days).

$\mathrm{Du}=$ Distribution uniformity of the drip irrigation system, an average value of 0.8 was used as determined in the beginning of each season (Ismail, 2002).

LR = Leaching requirements, (LR was not considered to avoid the effect of excess water on the irrigation stress treatment, $\mathrm{I}_{1}$ ).

\section{Reference evapotranspiration $\left(E T_{o}\right)$ :}

The $\mathrm{ET}_{\mathrm{o}}$ values were calculated from class ' $\mathrm{A}$ ' pan measurements located at the experimental site as follows:

$$
\mathrm{ET}_{\mathrm{o}}=\mathrm{E}_{\mathrm{pan}} \times \mathrm{K}_{\mathrm{pan}} \quad \text { (Doorenbos and Pruitt, 1984) }
$$

where:

$\mathrm{E}_{\mathrm{pan}}$ is the measured pan evaporation values ( $\mathrm{mm} /$ day).

$\mathrm{K}_{\mathrm{pan}}$ is a pan coefficient used to estimate $\mathrm{ET}_{\mathrm{o}}$ based on the siting and local climate. In this experiment, $\mathrm{K}_{\mathrm{pan}}=0.75$ employed.

Based on the actual emitter discharges, the irrigation time was calculated according to the equation given by Ismail (2002) as follows:

$$
t=\frac{A W \times A}{1000 \times q}
$$

where:

$\mathrm{t} \quad=$ irrigation time $(\mathrm{h})$ 
A = wetted area $\left(\mathrm{m}^{2}\right)$

$\mathrm{q}=$ emitter discharge $\left(\mathrm{m}^{3} / \mathrm{h}\right)$

$\mathrm{AW}=$ depth applied irrigation water $(\mathrm{mm})$

\section{Crop evapotranspiration (ETc):}

Crop evapotranspiration values were calculated according to Israelson and Hansen (1962) using the following equation:

$$
E T_{c}=10 \times \sum_{i=1}^{2}\left(\frac{\theta_{2}-\theta_{1}}{100}\right) \times B_{d} \times d
$$

Where:

for $\mathrm{ET}_{\mathrm{c}}$ in $\mathrm{mm}$, where:

$\mathrm{i} \quad=$ number of soil layers

$\Theta_{2}=$ available soil moisture content 48 hours after irrigation (\%)

$\Theta_{1}=$ available soil moisture content before irrigation (\%)

$\mathrm{d}=$ depth of soil layers $(\mathrm{cm})$

$\mathrm{B}_{\mathrm{d}}=$ bulk density $\left(\mathrm{g} \mathrm{cm}^{-3}\right)$

Water productivity $(W P)$ :

The WP values were calculated according to Jensen (1983) as follows:

$$
W P_{-}=\frac{\text { Tomato fruit yield }\left(\frac{\mathrm{kg}}{\mathrm{ha}}\right)}{\text { Applied irrigation water }\left(\frac{\mathrm{m} 3}{\mathrm{ha}}\right)}
$$

Leaf water potential $\left(\Psi_{\text {leaf }}\right)$ :

Leaf water potential values (MPa) were measured with a portable pressure chamber apparatus (Soil Moisture Equipment Corp, Santa Barbara, CA, USA). Measurements were carried out on one adult leaf from each irrigation treatment at flowering, yield formation, and ripening growth stages.

Crop coefficient $(\mathrm{Kc})$ :

The local crop coefficient values for tomato crop were calculated as follows:

$$
K c=\frac{E T c}{E T o}
$$

Yield response factor $\left(K_{y}\right)$ :

The yield response factor, which links relative yield decrease to relative evapotranspiration deficit, is expressed by the standard formulation given by Vaux and Pruitt (1983) as follows: 


$$
K_{y}=\left[\left(1-\frac{Y_{a}}{Y_{m}}\right) /\left(1-\frac{A W_{a}}{A W_{m}}\right)\right]
$$

where:

$\mathrm{K}_{\mathrm{y}}$ :

yield response factor

$\mathrm{Y}_{\mathrm{a}}$ : actual yield (t/ha)

$Y_{\mathrm{m}}$ : maximum yield ( $\mathrm{t} / \mathrm{ha}$ )

$\mathrm{AW}_{\mathrm{a}}$ : $\quad$ actual amount of applied irrigation water $\left(\mathrm{m}^{3} / \mathrm{ha}\right)$

$\mathrm{AW}_{\mathrm{m}}$ : maximum amount of applied irrigation water $\left(\mathrm{m}^{3} / \mathrm{ha}\right)$

\section{Statistical analysis:}

The obtained data were analyzed using the Cohort software (1986) statistical package. Average values from the four replicates of each treatment were interpreted using the analysis of variance (ANOVA). The Duncan's Multiple Range Test was used for comparisons between means according to Steel and Torrie (1980).

\section{RESULTS AND DISCUSSION}

\section{Tomato yield:}

The effect of irrigation, nitrogen fertilizer, and mulch treatments on tomato yield is presented in Table 4. Results showed significant effects of all tested variables on tomato yield. The application of irrigation treatment $\mathrm{I}_{3}$ produced 69.65 and 56.34 ton/ha in the first and second seasons, respectively. The obtained yields were significantly higher than those obtained from the application of $I_{1}$ (50.08 and 43.66 ton/ha) and $I_{2}(52.28$ and 47.92 ton/ha) irrigation treatments in the two growing seasons. Therefore, the application of $125 \%$ of $\mathrm{ET}_{\mathrm{o}}$ is recommended for high tomato fruit yield in the sandy soil at the experimental site. The results were consistent with the findings of Topcu et al. (2007); they demonstrated that the yield reduction was limited to $10-20 \%$ corresponding to about $25-50 \%$ reduction of irrigation water applied.

Results revealed also that, application of $100 \%$ of the recommended nitrogen rate significantly increased tomato yield by 20.8 and $29.6 \%$ compared to that obtained from the application of $75 \%$ of the recommended nitrogen rate in the two respective seasons. Also, the application of the plant residue mulch significantly increased tomato yield by 7.6 and $14.7 \%$ compared to that obtained from no mulch treatment in the first and second 
seasons, respectively as shown in Table 4. The interaction between irrigation and nitrogen treatments was significant. The maximum tomato fruit yields of 63.24 and 53.77 ton/ha were obtained by irrigation treatment $\mathrm{I}_{3}$ and the application of $100 \%$ of recommended nitrogen rate $\left(\mathrm{N}_{2}\right)$ in the two respective seasons. From the obtained results it could be concluded that, the combined effect of $\mathrm{I}_{3}, \mathrm{~N}_{2}$, and $\mathrm{M}$ treatment is recommended to produce the highest tomato yield at the experimental site and in areas with similar conditions. The obtained results are in agreement with those reported by Kay (1978), Sarg (1983), Jalota and Prihar (1998), Mahajan and Singh (2006), Berihun (2011), Samaila et al. (2011), and Biswas et al. (2015).

Table 4: Tomato yield (ton/ha) as affected by irrigation, nitrogen fertilizer, and mulch treatments during the 2012 and 2013 summer growing seasons.

\begin{tabular}{|c|c|c|}
\hline Treatments & 2012 & 2013 \\
\hline $\begin{array}{l}\text { Irrigation (I): } \\
I_{1} \\
I_{2} \\
I_{3} \\
\text { L.S.D. at } 5 \%\end{array}$ & $\begin{array}{c}50.08 \\
52.28 \\
69.65 \\
\mathbf{6 . 2 4}\end{array}$ & $\begin{array}{c}43.66 \\
47.92 \\
56.34 \\
\mathbf{4 . 4 8}\end{array}$ \\
\hline $\begin{array}{l}\text { Nitrogen(N): } \\
N_{1} \\
N_{2} \\
\text { L.S.D at } 5 \%\end{array}$ & $\begin{array}{r}51.90 \\
62.67 \\
\mathbf{5 . 5 7} \\
\end{array}$ & $\begin{array}{c}42.95 \\
55.66 \\
\mathbf{1 . 4 8} \\
\end{array}$ \\
\hline $\begin{array}{l}\text { Mulch }(\mathrm{M}): \\
\mathrm{M}_{0} \\
\mathrm{M} \\
\text { L.S.D at } 5 \%\end{array}$ & $\begin{array}{c}55.18 \\
59.35 \\
\mathbf{3 . 0 9}\end{array}$ & $\begin{array}{c}45.94 \\
52.68 \\
\mathbf{1 . 0 5}\end{array}$ \\
\hline \multicolumn{3}{|l|}{ Interaction $(\mathrm{I} * \mathrm{~N})$ : } \\
\hline $\begin{array}{l}\mathrm{I}_{1} \mathrm{~N}_{1} \\
\mathrm{I}_{2} \mathrm{~N}_{1} \\
\mathrm{I}_{3} \mathrm{~N}_{1} \\
\mathrm{I}_{1} \mathrm{~N}_{2} \\
\mathrm{I}_{2} \mathrm{~N}_{2} \\
\mathrm{I}_{3} \mathrm{~N}_{2}\end{array}$ & $\begin{array}{l}53.12 \\
53.86 \\
59.65 \\
56.71 \\
57.45 \\
63.24\end{array}$ & $\begin{array}{l}45.31 \\
46.73 \\
49.53 \\
49.54 \\
50.96 \\
53.77\end{array}$ \\
\hline L.S.D at $5 \%$ & 9.64 & 2.57 \\
\hline Interaction $(\mathrm{I} * \mathrm{M})$ & N.S. & N.S. \\
\hline Interaction $(\mathrm{N} * \mathrm{M})$ & N.S. & N.S. \\
\hline Interaction $(\mathrm{I} * \mathrm{~N} * \mathrm{M})$ & N.S. & N.S. \\
\hline
\end{tabular}

\section{Leaf water potential ( $\left.\Psi_{\text {leaf }}\right)$ :}

Leaf water potential values for the two growing seasons are presented in Table 5. In general, the leaf water potential $\left(\Psi_{\text {leaf }}\right)$ values decreased with 
growing stages of tomato crop under all treatments in the two growing seasons. The mean leaf water potential values were $-1.13,-1.23$, and -1.29 $\mathrm{MPa}$ for the flowering, yield formation, and ripening growth stages, respectively in the first season, and they were $-1.19,-1.31$, and $-1.41 \mathrm{MPa}$ in the second season. Also, mean leaf water potential values were less with increasing irrigation water and mulching. The results agree with those of Goghlan (2007) who stated that decreasing soil moisture increased leaf water potential values of tomato crop.

Table 5: Leaf water potential $\Psi_{\text {leaf }}$, (MPa) for tomato crop as affected by irrigation, nitrogen fertilizer and mulch treatments during 2012 and 2013 summer growing season.

\begin{tabular}{|c|c|c|c|c|c|c|c|c|}
\hline Season & \multicolumn{4}{|c|}{2012} & \multicolumn{4}{|c|}{2013} \\
\hline Treatments & $\begin{array}{c}\text { Floweri } \\
\text { ng }\end{array}$ & $\begin{array}{c}\text { Yield } \\
\text { format } \\
\text { ion }\end{array}$ & $\begin{array}{l}\text { Ripeni } \\
\text { ng }\end{array}$ & $\begin{array}{c}\text { Seaso } \\
\mathrm{n} \\
\text { averag } \\
\mathrm{e}\end{array}$ & $\begin{array}{c}\text { Flowerin } \\
\mathrm{g}\end{array}$ & $\begin{array}{c}\text { Yield } \\
\text { formatio } \\
n\end{array}$ & $\begin{array}{l}\text { Ripenin } \\
\mathrm{g}\end{array}$ & $\begin{array}{c}\text { Seaso } \\
\mathrm{n} \\
\text { averag } \\
\mathrm{e}\end{array}$ \\
\hline $\mathrm{I}_{1} \mathrm{~N}_{1} \mathrm{M}$ & -1.10 & -1.20 & -1.32 & -1.21 & -1.30 & -1.23 & -1.44 & -1.32 \\
\hline $\mathrm{I}_{1} \mathrm{~N}_{1} \mathrm{M}_{\mathrm{o}}$ & -1.25 & -1.37 & -1.45 & -1.36 & -1.35 & -1.35 & -1.50 & -1.40 \\
\hline $\mathrm{I}_{1} \mathrm{~N}_{2} \mathrm{M}$ & -1.10 & -1.35 & -1.38 & -1.28 & -1.26 & -1.23 & -1.35 & -1.28 \\
\hline $\mathrm{I}_{1} \mathrm{~N}_{2} \mathrm{M}_{\mathrm{o}}$ & -1.40 & -1.38 & -1.33 & -1.37 & -1.33 & -1.30 & -1.50 & -1.38 \\
\hline Average $\mathbf{I}_{1}$ & -1.21 & -1.33 & -1.37 & -1.31 & -1.31 & -1.28 & -1.45 & -1.35 \\
\hline $\mathrm{I}_{2} \mathrm{~N}_{1} \mathrm{M}$ & -1.20 & -1.26 & -1.30 & -1.25 & -1.17 & -1.13 & -1.26 & -1.19 \\
\hline $\mathrm{I}_{2} \mathrm{~N}_{1} \mathrm{M}_{\mathrm{o}}$ & -1.40 & -1.35 & -1.45 & -1.40 & -1.23 & -1.37 & -1.38 & -1.33 \\
\hline $\mathrm{I}_{2} \mathrm{~N}_{2} \mathrm{M}$ & -0.97 & -1.15 & -1.27 & -1.13 & -1.21 & -1.33 & -1.43 & -1.32 \\
\hline $\mathrm{I}_{2} \mathrm{~N}_{2} \mathrm{M}_{\mathrm{o}}$ & -1.26 & -1.26 & -1.47 & -1.33 & -1.30 & -1.47 & -1.47 & -1.41 \\
\hline Average I & -1.21 & -1.26 & -1.37 & -1.28 & -1.23 & -1.33 & -1.39 & -1.31 \\
\hline $\mathrm{I}_{3} \mathrm{~N}_{1} \mathrm{M}$ & -0.95 & -1.07 & -0.98 & -1.00 & -1.04 & -1.27 & -1.34 & -1.22 \\
\hline $\mathrm{I}_{3} \mathrm{~N}_{1} \mathrm{M}_{\mathrm{o}}$ & -1.10 & -1.18 & -1.20 & -1.16 & -1.12 & -1.37 & -1.47 & -1.32 \\
\hline $\mathrm{I}_{3} \mathrm{~N}_{2} \mathrm{M}$ & -0.73 & -1.00 & -1.08 & -0.94 & -0.93 & -1.34 & -1.37 & -1.21 \\
\hline $\mathrm{I}_{3} \mathrm{~N}_{2} \mathrm{M}_{\mathrm{o}}$ & -1.10 & -1.18 & -1.20 & -1.16 & -1.10 & -1.40 & -1.40 & -1.30 \\
\hline Average I 3 & -0.97 & -1.11 & -1.12 & -1.07 & -1.05 & -1.35 & -1.40 & -1.26 \\
\hline $\begin{array}{l}\text { Overall } \\
\text { average }\end{array}$ & -1.13 & -1.23 & -1.29 & -1.22 & -1.19 & -1.31 & -1.41 & -1.30 \\
\hline
\end{tabular}

\section{Irrigation applied water (AW):}

Monthly and total depths of applied irrigation water $(\mathrm{mm})$ during the two growing seasons are presented in Table 6 . Results showed the normal trend of increasing applied irrigation water with the advance in plant growth and the decrease at the ripening stage. The highest monthly value of applied irrigation water occurred during July and August in both seasons for all irrigation treatments. The total amount of applied irrigation water for 75, 100 , and $125 \%$ of $\mathrm{ET}_{\mathrm{o}}$ irrigation treatments were 583, 699 and $816 \mathrm{~mm}$ in 
the first season, while they were 526, 682, and $838 \mathrm{~mm}$ in the second season, respectively. The data are in agreement with those reported by Hanson and May (2006) who indicated that, the amounts of applied irrigation water for tomato crop varied between 582 and $905 \mathrm{~mm} /$ season. Table 6: Monthly and total depths of applied irrigation water $(\mathrm{mm})$ for tomato crop as affected by irrigation treatments during 2012 and 2013 summer growing season.

\begin{tabular}{|l|c|c|c|c|c|c|c|c|c|c|c|c|}
\hline Season & \multicolumn{9}{|c|}{2012} & \multicolumn{7}{|c|}{2013} \\
\hline $\begin{array}{l}\text { Irrigation } \\
\text { treatments }\end{array}$ & Jun. & Jul. & Aug. & Sep. & Oct. & Total & Jun. & Jul. & Aug. & Sep. & Oct. & Total \\
\hline I1 & 32.7 & 199.7 & 139.5 & 132.0 & 78.8 & $\mathbf{5 8 2 . 7}$ & 57.0 & 157.0 & 159.0 & 127.5 & 24.7 & $\mathbf{5 2 5 . 7}$ \\
\hline I2 & 32.7 & 199.7 & 186.0 & 176.0 & 105.0 & $\mathbf{6 9 9 . 4}$ & 57.0 & 210.0 & 212.0 & 170.0 & 33.0 & $\mathbf{6 8 2 . 0}$ \\
\hline I3 & 32.7 & 199.7 & 232.5 & 220.0 & 131.3 & $\mathbf{8 1 6 . 2}$ & 57.0 & 262.5 & 265.0 & 212.5 & 41.0 & $\mathbf{8 3 8 . 0}$ \\
\hline
\end{tabular}

\section{Yield response to water:}

Data illustrated in Fig (1) indicated that the relation between tomato yield "Y" (t/ha) and applied irrigation water "AW" (mm) was a liner relation. The obtained relation is expressed by the following formula

$$
Y=12.9+0.06 \mathrm{AW} \quad R^{2}=0.64
$$

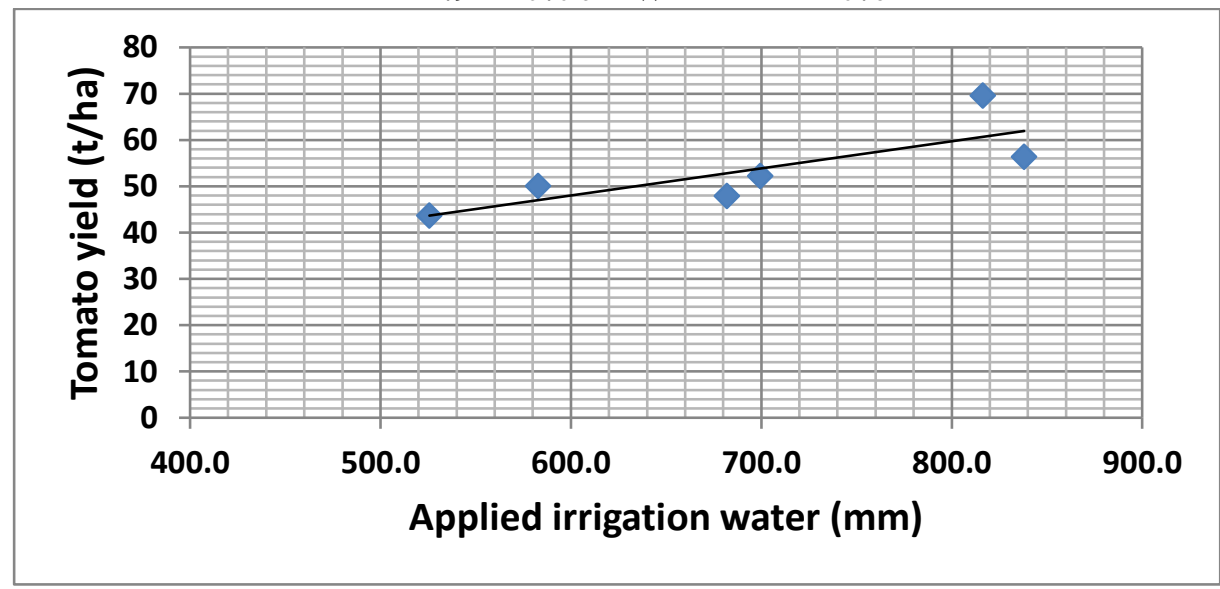

Fig. 1. Relationship between seasonal applied irrigation water $(\mathrm{mm})$ and tomato yield (t/ha).

\section{Crop evapotranspiration (ET $\mathbf{T}_{\mathrm{c}}$ ):}

The calculated $\mathrm{ET}_{\mathrm{c}}$ values for tomato crop during the two growing seasons are presented in Table 7. The values were 498, 549, and 573mm in 2012 for the 75,100 , and $125 \%$ of $\mathrm{ET}_{\mathrm{o}}$ irrigation treatments, respectively. The respective values for the $2^{\text {nd }}$ season were 431,501 , and $574 \mathrm{~mm}$. The 
highest monthly $\mathrm{ET}_{\mathrm{c}}$ values occurred during August. The results are in agreement with those reported by Hanson and May (2006) who indicated that the calculated $\mathrm{ET}_{\mathrm{c}}$ values for tomato crop varied between 528 and 630 $\mathrm{mm}$ per season. The results were also in close agreement with those reported by Goghlan (2007) who showed that water consumption by tomato crop varied between $455 \mathrm{~mm}$ per season for regulated deficit irrigation treatment and $532 \mathrm{~mm} / \mathrm{season}$ for full irrigation treatment.

Table 7. Water consumptive use values $(\mathrm{mm})$ for tomato crop as affected by irrigation treatments during 2012 and 2013 summer growing season.

\begin{tabular}{|l|c|c|c|c|c|c|c|c|c|c|c|c|}
\hline Season & \multicolumn{9}{|c|}{2012} & & & \multicolumn{6}{|c|}{2013} & & \\
\hline $\begin{array}{l}\text { Irrigation } \\
\text { treatments }\end{array}$ & Jun. & Jul. & Aug. & Sep. & Oct. & Total & Jun. & Jul. & Aug. & Sep. & Oct. & Total \\
\hline $\mathrm{I}_{1}$ & 16 & 140 & 160 & 112 & 70 & $\mathbf{4 9 8}$ & 25 & 132 & 144 & 110 & 20 & $\mathbf{4 3 1}$ \\
\hline $\mathrm{I}_{2}$ & 16 & 140 & 181 & 130 & 82 & $\mathbf{5 4 9}$ & 25 & 140 & 170 & 132 & 34 & $\mathbf{5 0 1}$ \\
\hline $\mathrm{I}_{3}$ & 16 & 140 & 197 & 139 & 81 & $\mathbf{5 7 3}$ & 25 & 168 & 191 & 151. & 39 & $\mathbf{5 7 4}$ \\
\hline
\end{tabular}

\section{Applied water productivity (AWP):}

The effect of irrigation and nitrogen fertilizer treatments on AWP values for the two growing seasons is presented in Table 8. Results showed that maximum AWP values were obtained from the interaction of $I_{1} N_{2}$ in both seasons. The maximum values were 9.73 and $9.42 \mathrm{~kg}$ tomato $/ \mathrm{m}^{3}$ based on the applied irrigation water for first and second seasons, respectively. It is clear from the results that AWP values from the first were higher than those from the second growing season due to higher tomato yield. The findings were in line with those reported by Doorenbos et al. (1979). Results agree also with those of Goghlan (2007) who stated that, AWP values decreased with increasing irrigation water. He reported AWP values for tomato crop of 6.15 and $7.20 \mathrm{~kg} / \mathrm{m}^{3}$ for applied water using the 100 and $75 \%$ of ETo irrigation treatments, respectively.

Table 8: The AWP for tomato crop ( $\mathrm{kg}$ tomato $/ \mathrm{m}^{3}$ water applied) as affected by irrigation and fertilizer treatments during 2012 and 2013 growing seasons.

\begin{tabular}{|l|l|c|}
\hline \multirow{2}{*}{ Treatments } & \multicolumn{2}{|c|}{ AWP $\left(\mathrm{kg}\right.$ tomato/m ${ }^{3}$ water applied) } \\
\cline { 2 - 3 } & 2012 & 2013 \\
\hline $\mathrm{I}_{1} \mathrm{~N}_{1}$ & 9.12 & 8.62 \\
$\mathrm{I}_{2} \mathrm{~N}_{1}$ & 7.70 & 6.85 \\
$\mathrm{I}_{3} \mathrm{~N}_{1}$ & 7.31 & 5.91 \\
$\mathrm{I}_{1} \mathrm{~N}_{2}$ & 9.73 & 9.42 \\
$\mathrm{I}_{2} \mathrm{~N}_{2}$ & 8.21 & 7.47 \\
$\mathrm{I}_{3} \mathrm{~N}_{2}$ & 7.75 & 6.42 \\
\hline
\end{tabular}




\section{Reference evapotranspiration (ET $\left.\mathbf{E}_{\mathbf{0}}\right)$ and crop coefficient $\left(\mathrm{K}_{\mathbf{C}}\right)$ :}

Monthly $\mathrm{ET}_{\mathrm{o}}$ values determined from class ' $\mathrm{A}$ ' pan, water consumption for the $\mathrm{I}_{3}\left(125 \% \mathrm{ET}_{\mathrm{o}}\right)$ treatment, and the calculated crop coefficient $\left(\mathrm{K}_{\mathrm{C}}\right)$ values are presented in Table 9. Monthly $\mathrm{ET}_{\mathrm{o}}$ values were low in June and increased to reach maximum values in July for both growing seasons. Average $\mathrm{K}_{\mathrm{c}}$ values were 0.51 at initial stage of growth during June, reached its maximum value of 0.98 during August, and then decreased to 0.71 during October. The results agree well with the $\mathrm{K}_{\mathrm{C}}$ values reported by Doorenbos et al. (1979) and Doorenbos and Pruitt (1984). The Kc values were close to those of Amayreh and Al-Abed (2005) who reported $\mathrm{K}_{\mathrm{c}}$ values of $0.69,0.82,1.19$, and 0.76 for the vegetative, flowering, yield formation, and ripening growth stages, respectively. On the other hand, the average $\mathrm{K}_{\mathrm{c}}$ values reported by Hanson and May (2006) ranged from 0.19 at $10 \%$ canopy coverage to 1.08 at $90 \%$ canopy coverage.

Table 9: Crop coefficient $\left(\mathrm{K}_{\mathrm{C}}\right)$ for tomato crop as affected by irrigation treatments under drip irrigation system in sandy soils during 2012 and 2013 summer growing seasons.

\begin{tabular}{|c|c|c|c|c|c|c|c|}
\hline Season & \multicolumn{3}{|c|}{2012} & \multicolumn{3}{|c|}{2013} & \multirow{2}{*}{$\begin{array}{c}2-\mathrm{yr} \\
\text { average } \\
\mathrm{K}_{\mathrm{c}}\end{array}$} \\
\hline Month & $\begin{array}{c}\mathrm{ET}_{\mathrm{o}} \\
(\mathrm{mm})\end{array}$ & $\mathrm{ET}_{\mathrm{c}}(\mathrm{mm})$ & $\mathrm{K}_{\mathrm{C}}$ & $\begin{array}{c}\mathrm{ET}_{\mathrm{o}} \\
(\mathrm{mm})\end{array}$ & $\begin{array}{l}\text { ETc } \\
(\mathrm{mm})\end{array}$ & $\mathrm{K}_{\mathrm{c}}$ & \\
\hline June & 32.7 & 16 & 0.49 & 48.0 & 25 & 0.52 & 0.51 \\
\hline July & 208.2 & 140 & 0.67 & 217.0 & 168 & 0.77 & 0.72 \\
\hline August & 188.9 & 197 & 1.04 & 210.0 & 191 & 0.91 & 0.98 \\
\hline September & 177.9 & 139 & 0.78 & 198.0 & 151 & 0.76 & 0.77 \\
\hline October & 107.5 & 81 & 0.75 & 58.0 & 39 & 0.67 & 0.71 \\
\hline $\begin{array}{l}\text { Season } \\
\text { average }\end{array}$ & & & 0.75 & & & 0.73 & 0.74 \\
\hline
\end{tabular}

\section{Yield Response factor $(\mathrm{Ky})$ :}

Average tomato yields obtained from the irrigation treatments in the two growing seasons were fitted into a linear equation relating the relative yield decrease to the relative decrease in applied irrigation water (Fig. 2). The equation representing the relation is:

$$
Y=0.82 X, \quad R^{2}=0.55
$$

where:

$\mathrm{Y}$ : represents relative yield reduction $\left(1-\mathrm{Y}_{\mathrm{a}} / \mathrm{Y}_{\mathrm{m}}\right)$,

$\mathrm{X}$ : represents relative reduction in applied irrigation water $\left(1-\mathrm{AW}_{\mathrm{a}} / \mathrm{AW}_{\mathrm{m}}\right)$, 
the constant 0.82 represents the yield response factor $(\mathrm{Ky})$ that indicates the sensitivity of tomato crop to the deficit of applied irrigation water.

The obtained Ky value under the experimental condition was about 22\% less than the Ky $=1.05$ value reported for tomato crop by Doorenbos et al. (1979) under deficit irrigation conditions for the whole growing season. This difference could be due to the fact that the tested treatments were not applied from seedlings transplanting (i.e. not exposing tomato plants to water stress for the whole season). Also, the short irrigation intervals (2 to 3 days) in this experiment could have a pronounced effect on decreasing the effect of water stress on the yield. The observed Ky value was close to that reported for tomato crop $(\mathrm{Ky}=0.68)$ by Kirda et al. $(2004)$ and $(\mathrm{Ky}=$ 0.78) by Goghlan (2007).

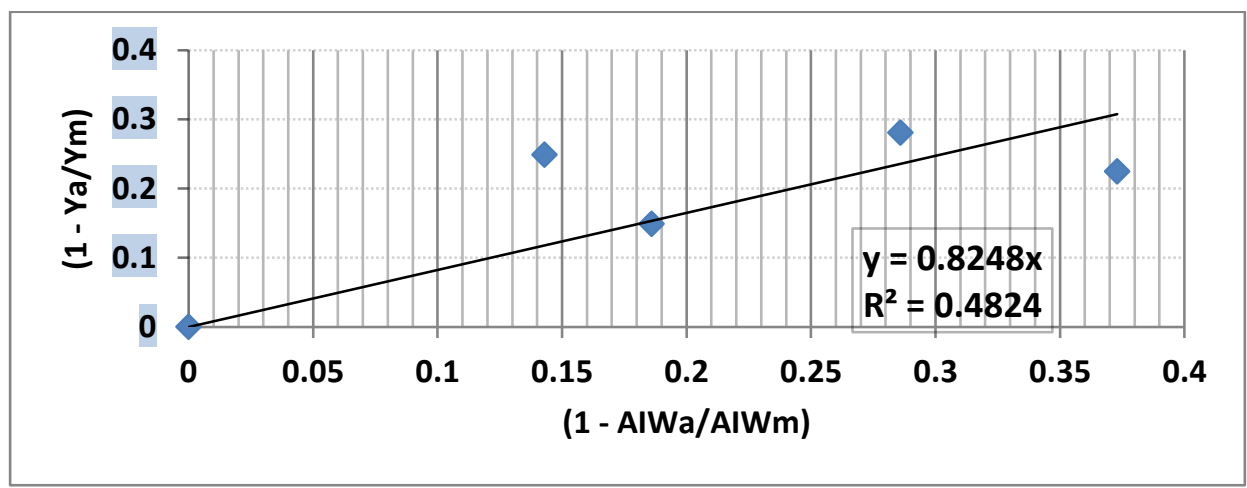

Fig. 2. Relative yield decreases as a function of relative decrease in applied irrigation water.

\section{CONCLUSIONS}

The results of this research could be summarized as following:

- There is a significant effect of irrigation, nitrogen fertilizer, and plant residue mulch treatments on tomato fruit yield.

- Applied irrigation water values were 583, 699 and $816 \mathrm{~mm}$ for the 75\%, $100 \%$, and $125 \%$ of ETo irrigation treatments respectively in the first season, while in the second season they were 526, 682 and $838 \mathrm{~mm}$ for the same respective treatments.

- Crop evapotranspiration values $\left(\mathrm{ET}_{\mathrm{c}}\right)$ were 498, 549, and $573 \mathrm{~mm}$ for the $75 \%, 100 \%$, and $125 \%$ of ETo irrigation treatments respectively in the first season. While in the second season, the $\mathrm{ET}_{\mathrm{c}}$ values were 431 , 501 and $574 \mathrm{~mm}$ for the same respective treatments. 
- Maximum AWP values were 9.73 and $9.42 \mathrm{~kg} / \mathrm{m}^{3}$ of applied irrigation water in the first and second seasons, respectively.

- Seasonal mean crop coefficient $\left(\mathrm{K}_{\mathrm{c}}\right)$ and yield response factor $\left(\mathrm{K}_{\mathrm{y}}\right)$ values for tomato crop grown under the newly reclaimed sandy soil conditions at Nubaria region were 0.74 and 0.82 , respectively.

- Under similar field conditions, the irrigation with amount of water equal to $125 \%$ of $\mathrm{ET}_{\mathrm{o}}, 100 \%$ of recommended nitrogen fertilizer, and adding mulch of plant residues is recommended to produce high tomato crop yield in sandy soils.

\section{Acknowledgment:}

The authors would like to thank the Arab Fund for Economic and Social Development (AFESD) for funding this research through the Research Collaboration Agreement between The Agricultural Research Center of the Egyptian Ministry of Agriculture and Land Reclamation (ARC) and the International Centre for Agricultural Research in the Dry Areas (ICARDA) under the title "Community-Based Optimization of Management of Scarce Water Resources in Agriculture".

\section{REFRENCES}

Amayreh, J. and N. Al-Abed. (2005). Development crop coefficients for field-grown tomato (Lycopersicon esculentum, mill.) under drip irrigation with black plastic mulch. Agric. Management, 73: 247-254.

Berihun, B. (2011). Effect of mulching and amount of water on the yield of tomato under drip irrigation. Journal of Horticulture and forestry Vol.3 (7), pp, 200-206, July 2011.

Bhella, H.S. (1988). Tomato response of trickle irrigation and black polyethylene mulch.J. Am. Soc. Hort. Sci. 113 (4):543-545.

Biswas, S.K., A.R. Akanda, M.S. Rahman, and M.A. Hossain. (2015). Effect of drip irrigation and mulching on yield water use efficiency and economics of tomato. Plant soil Environ. vol. 61 ,2015 No. 3 :97102.

Black, G., and K. Hartge. (1986). Bulk Density. In Klute, A. (ed.): Methods of Soil Analysis. Physical and Mineralogical Methods. $\left(2^{\text {ed }}\right.$ 
Ed.). Soil Science Society of American, Madison, WI, USA. (363377).

Cohort Software (1986). Costat statistical package (version 3.03). P.O. Box 1149, Berkeley, CA, 94 701, USA.

Doorenbos, J., A.H. Kassam, C.I.M. Bentvelsen, V. Branscheid, J.M.G.A. Plusje, M. Smith, G.O. Uittenbogaard, and H.K. Van der Wal. (1979). Yield response to water, Irrigation and Drainage Paper no. 33, FAO, Rom, Italy.

Doorenbos, J., and W.O. Pruitt. (1984). Crop water requirements, Irrigation and Drainage Paper no. 24, Revised, FAO, Rom, Italy.

FAO (1970). Physical and Chemical Methods of Soil and Water Analysis. Soils Bull. No. 10, FAO, Rome, Italy.

FAO (2000). Fertilizer requirements in 2015 and 2030. Rome, Italy.

Goghlan, A. Kh. (2007). Effect of partial root one drying and deficit irrigation techniques on the response and water use efficiency of tomato crop in calcareous soil. $\mathrm{PhD}$ Thesis, Faculty of Agric., Alexandria Univ., Egypt.

Hanson, B.R., and D.M. May. (2006). Crop coefficients for drip irrigation processing tomato. Agric. Water Management. 81:381-399.

Imtiyaz M., N.P. Mgadla, B. Chepete, and E.O. Motholdi. (2000). Yield and economic returns of vegetable crops under varying irrigation. Irrigation Sci. 19:87-93.

Ismail, S.M. (2002). Design and management of field irrigation system. (in Arabic) 1st Ed. Monshat El-Maref publication Alexandria, Egypt.

Israelson, O.W., and V.E. Hansen. (1962). Irrigation principles and practices. 3rd Edit. Joohn wiely and sons I.nc. New York.

Jalota, S.K., and S.S. Priher. (1998). Reducing soil water evaporation with tillage and mulching. Iowa State University Press, Ames. JA, 142p. 
James. L.G. (1988). Principals of Farm Irrigation System Design. John Wiley and Sons, Inc., New York, USA.

Jensen, M.E. (1983). Design and Operation of farm irrigation system. Amer. Soc. Agric. Eng. Michigan, MSA. P827.

Kay, B.l. (1978). Mulching and chemical stabilizers for land reclamation in dry regions. PP467 - 483. In F.W. Schaller and P. Sutten, editors reclamation of drastically distributed lands. Am. Soc. Agronomy Madison W I.

Mahajan, G., and K.G. Singh. (2006). Response of greenhouse tomato to irrigation and fertigation. Agric. Water Management 84: 202-206.

Kirda, C., M. Cetin, Y. Dasgan, S.T opcu, H. Kaman, B. Ekici, M.R. Deric and A.I. Ozguven, 2004. Yield response of greenhouse grown tomato to partial rootzone drying and conventional deficit irrigation. Agric. Water Management, 69: 191-201.

Page, A.L., R.H. Miller. and D.R. Keeny. (1982). Methods of soil analysis. Amer. Soc. Agr. Inc. Madison, USA.

Raina, J.R., B.C. Thakur, and M.L. Verma. (1999). Effect of drip irrigation and polyethylene mulch on yield quality and water use efficiency of tomato. Indion J. Agric. sci., 69: 430-433.

Samaila, A.A, E.B. Amans, and B.A. Babaje. (2011). Yield and fruit quality of tomato as influenced by mulching, nitrogen and irrigation interval. Inter. Re. j. of Agric. Sci. and soil Sci. Vol.1 (3) PP 90-95.

Sarg, S.M. (1983). Drought resistance of some tomato varieties at different stages of growth. M. Sc. thesis faculty of Agric. Ain Shames Univ. Cairo, Egypt.

Steel, R.G., and J.H. Torrie. (1980). Principles and procedures of statistics $2^{\text {nd }}$ Edi., New York Mc. Grew Hill Book Company, 196 p.

Topcu, S., C. Kirda, Y. Dasgan, H. Kaman, M. Cetin, A. Yazici and M.A. Bacon. (2007). Yield response and N-fertilizer recovery of tomato grown under deficit irrigation. Europe J. Agronomy, 26: 6470. 
Vaux, H.J., and O.W. Pruitt. (1983). Crop water production functions. In D. Hillel (ed.) Advances in Irrigation. Volume 2. p. 61-93, Academic Press, NY, USA.

Vermeirn, L., and G.A. Gopling. (1984). Localized irrigation. FAO, Irrigation and Drainage Paper no. 36, Rome, Italy.

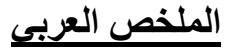

تأثير مستويات الرى، التسميد النيتروجينى، وتغطية التربة على الإنتاجية المائية

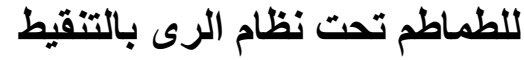

محمود عطيةة*، عاطف سويلم***، أحمد سلام* وأحمد عثمان*

أجريت التجربة البحثية فى المحطة البحثية بالبستان بمنطقة غرب النوبارية فى محافظة البحيرة

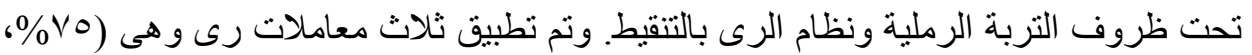

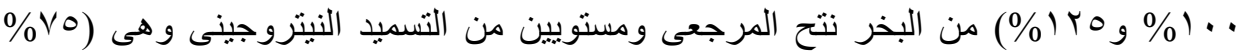

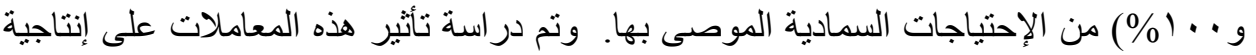

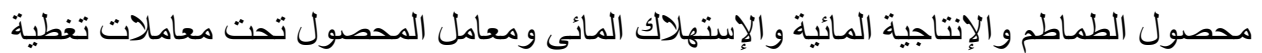

$$
\text { سطح التربة وبدون تغطية. }
$$

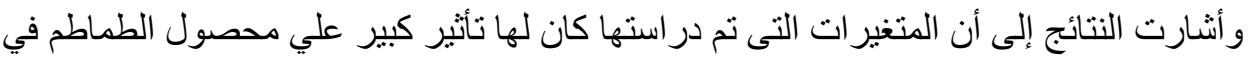

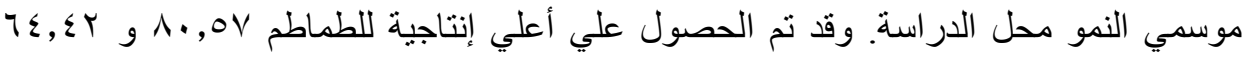

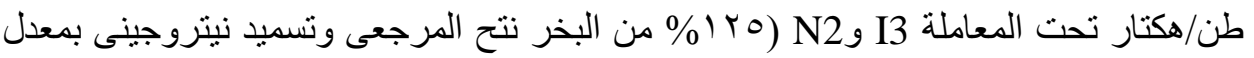

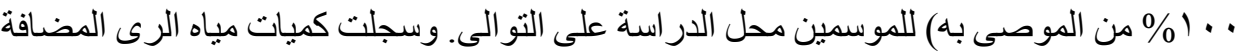

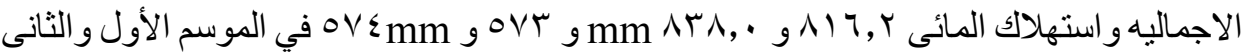

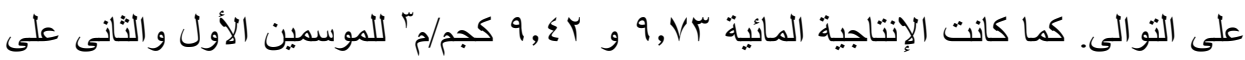

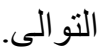

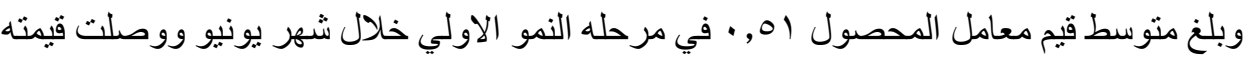

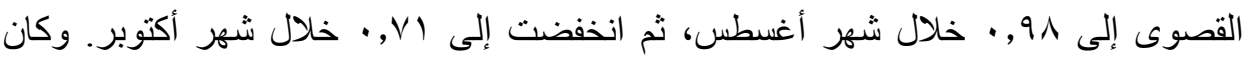

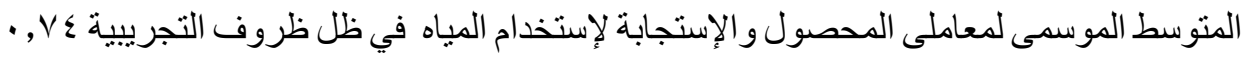

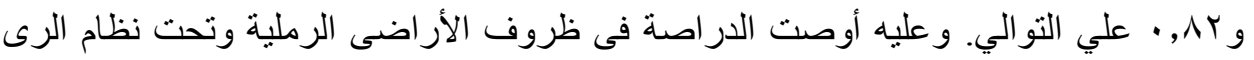

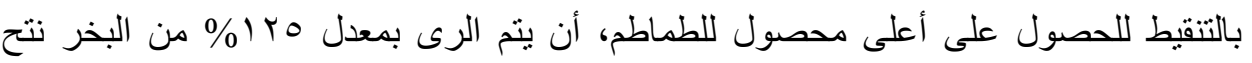

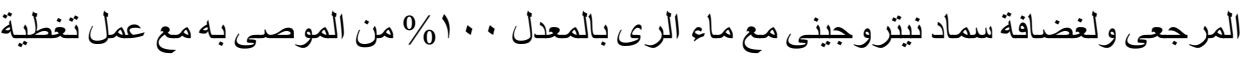

لسطح التربة بمخلفات المحصول لتقليل البقفد بالبخر من التربة.

* معهد بحوث الاراضى والمياه، مركز البحوث الزراعة الزية.

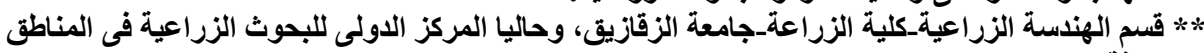
الجافة (إيكاردا). 